\title{
Description of the third instar larva of a hypogean ground beetle, Trechus alicantinus (Coleoptera: Carabidae: Trechinae)
}

\author{
Vicente M. Ortuño \& Ana Sofia P. S. Reboleira
}

Ortuño, V. M. \& Reboleira, A. S. P. S. 2010: Description of the third instar larva of a hypogean ground beetle, Trechus alicantinus (Coleoptera: Carabidae: Trechinae). - Entomol. Fennica 21: 33-42.

Description and illustrations are provided for the third instar larva of Trechus alicantinus Español, 1971 obtained from a laboratory breeding. This paper aims to contribute to increase the general knowledge about microendemic hypogean species of the east of the Iberian Peninsula. Besides, it expands the existing knowledge about the preimaginal stages of the genus Trechus and the whole tribe Trechini (Coleoptera, Carabidae). Larvae can give additional information about the life style of the species. Larvae can also express, even more than the imagos, some apomorphic characters, traditionally considered a result of adaptation to the hypogean habitat, such as the regression of ocular structures. The characteristic lack of stemmata is discussed. This type of event, which also appears in other Trechini larvae, is probably more related to phylogenetic lineages than with an adaptive response to hypogean environment.

V. M. Ortuño (corresponding author), Departamento de Zoología y Antropología Física, Facultad de Biología, Universidad de Alcalá, E-28871 - Alcalá de Henares, Madrid, Spain; E-mail: vicente.ortuno@uah.es

A. S. P. S. Reboleira, Centro de Estudos do Ambiente e do Mar (CESAM) and Departamento de Biologia, Universidade de Aveiro, Campus Universitário de Santiago,3810-Aveiro,Portugal; E-mail: sreboleira@ua.pt

Received 30 April 2009, accepted 14 September 2009

\section{Introduction}

The knowledge of Trechini larvae (sensu Serrano 2003) that inhabit the Iberian Peninsula is still in its nascent stage. There are known larvae of certain eurytopic species (Jeannel 1920, 1941, Luff 1993), e.g. Trechus quadristriatus (Schrank, 1781) and Trechus obtusus Erichson, 1837, and even from other species with more limited distribution but also beyond the peninsular scope (Coquerel 1850, Bolívar y Pieltain 1923, Boldori 1936, Luff 1993, Grebennikov 1996, among others), as is the case of Aepopsis robini (Laboulbène, 1849), Thalassophilus longicornis (Sturm, 1825) and Perileptus areolatus (Creutzer, 1799). But concerning the endemic species of the Iberian Peninsula, there are few species whose larvae have been studied, and always as a result of their capture in nature (Jeannel 1920, 1926a): Iberotrechus bolivari (Jeannel, 1913), Paraphaenops breuilianus Jeannel, 1916, Trechus distigma Kiesenwetter, 1851, Trechus pieltaini Jeannel, 1920 and Trechus breuili Jeannel, 1913. 
Data about immature insects can provide powerful tools for taxonomical and ecological studies of the species. The larva is a different expression of the same genetic material that can be found in the adult. There are several structures that can be identified and understood through the study of larvae (Bousquet \& Goulet 1984). Notation of setae and pores in the larvae can be an abundant source of characters and a good tool in order to establish phylogenetic relationships (Grebennikov \& Maddison 2005).

The present paper describes the third preimaginal stage of Trechus alicantinus Español, 1971 obtained from a laboratory breeding. This species is microendemic (sensu Rapoport 1975) for the Iberian Peninsula and lives in the northeast board of the Betic chain. It belongs to the "Trechus martinezi-lineage" (sensu Ortuño \& Arillo 2005) and, like its adelphospecies of the Iberian sphere (Ortuño \& Arillo 2005, Ortuño 2008), shows hypogean habits. The corological data, for the time being, locate this species only in underground habitat (two caves), located in two districts of the Alicante province (Spain): Comtat and la Marina Alta (Ortuño 2006). Nowadays, the knowledge of this species is limited to taxonomic data, based on external morphology (and genital anatomy) of the imago. Certain aspects of their biology and all preimaginal stages are still unknown.

\section{Material and methods}

Several imagos of T. alicantinus (3 males and 4 females) were collected in clayey and humid substratum in the Cueva del Somo in Castell de Castell (Alicante, Spain) during the rainy season (March 25 $\left.{ }^{\text {th }}, 2003\right)$. The specimens were placed in two terrariums at low temperature $\left(11-12{ }^{\circ} \mathrm{C}\right.$, the same temperature as in the afotic area of the cave). The first copulations were observed some weeks later. Consequently, larvae were obtained from the eggs. Seven larvae of several sizes were located in the terrarium (three larvae found on May, $2^{\text {nd }}$ and four larvae on October, $3^{\text {rd }}$ ). In order to unequivocally describe the larval instar-III the greatest larva (almost a centimeter long) was selected.

The larva was cleaned and preserved in

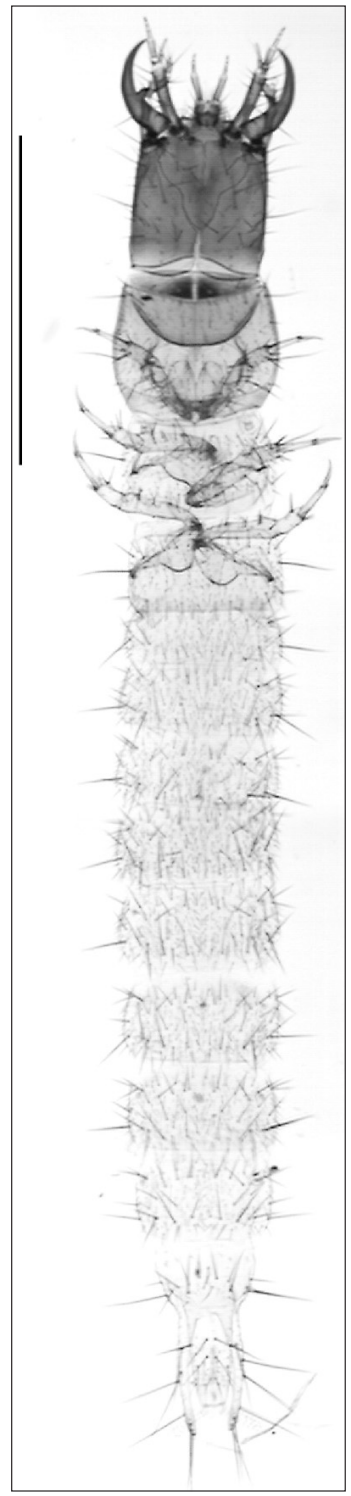

Fig. 1. Trechus alicantinus Español, 1971, habitus of the third instar larva, dorsal view. Scale bar: $2 \mathrm{~mm}$.
Scheerpeltz solution (70\% ethanol, 29\% distilled water, $1 \%$ acetic acid and glycerine). After examination, the selected larva was prepared in Hoyer's solution ( $30 \mathrm{~g}$ gum arabic, $20 \mathrm{ml}$ glycerine, $50 \mathrm{ml}$ distilled water, $200 \mathrm{~g}$ chloral hydrate) and studied on a microscope slide. Chloral hydrate was used as clearing agent of larval integument. Detailed analysis was made using a microscope and stereomicroscope, both with a drawing tube.

Notation of the primary setae and pores according to the homology method proposed by 


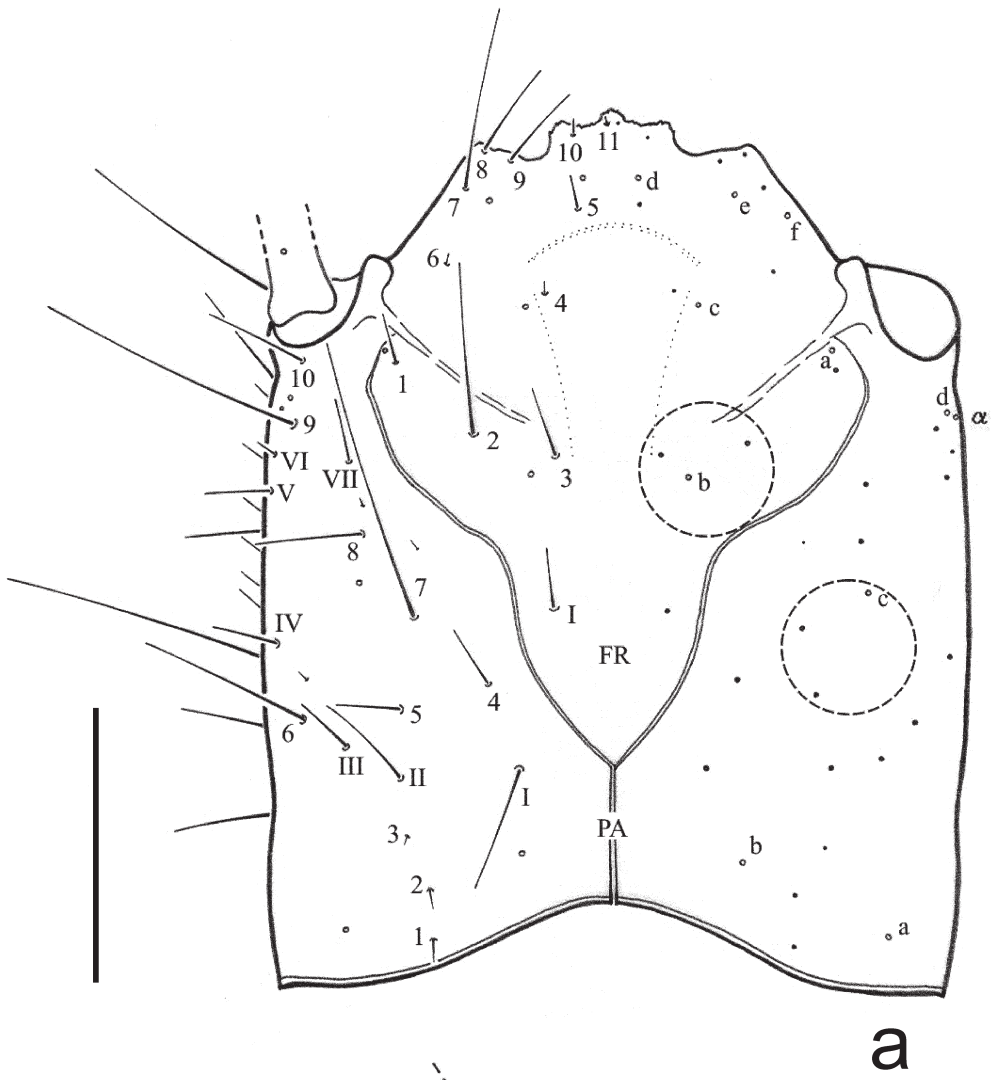

Fig. 2. Cephalic capsule.

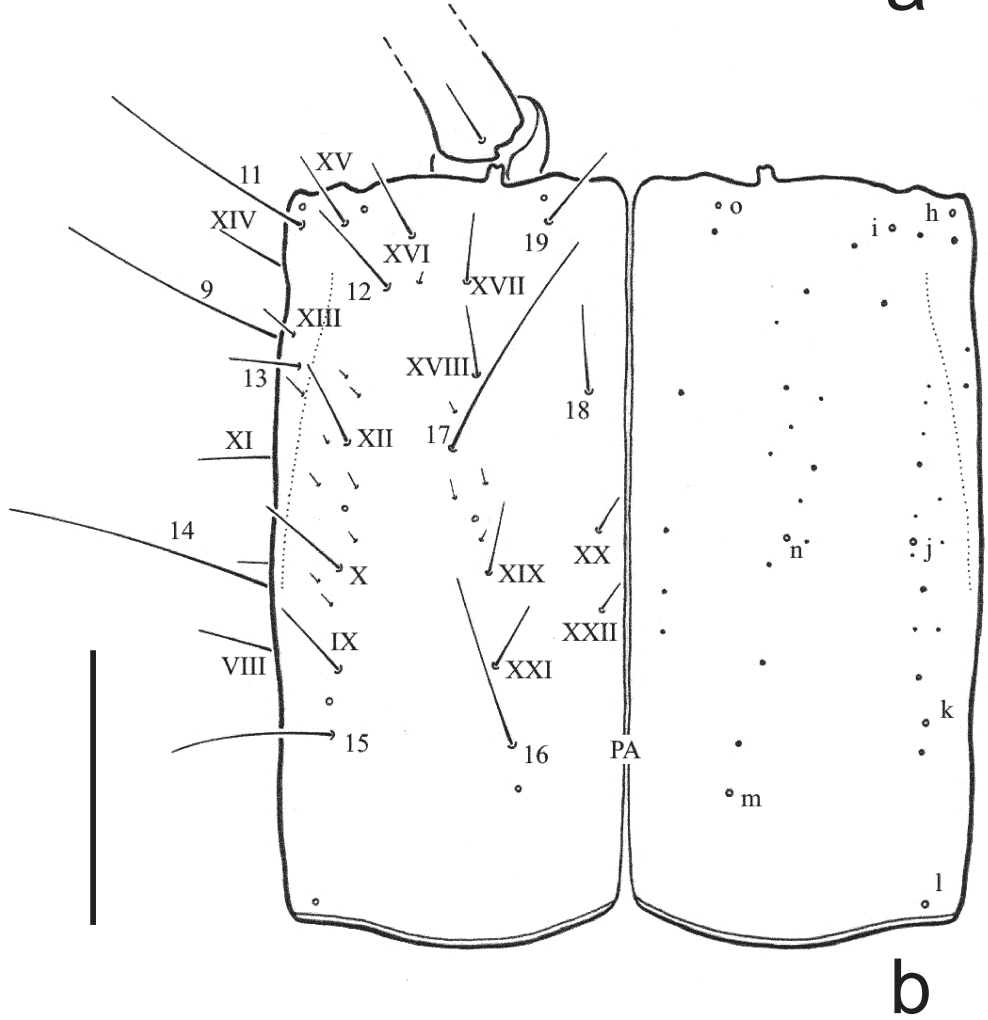

a. Dorsal view. - b. Ven-
tral view. Scale bar: $0.3 \mathrm{~mm}$. 
Bousquet \& Goulet (1984) and used by Makarov (1994) in the key to the genera of the Palearctic larvae of the Carabidae was used for this work. The presence of additional setae and pores, according to the archetypal model of Bousquet \& Goulet (1984), is marked in ascending order with Roman numerals (setae) and Greek letters (pores), following the same lines as Giachino (1989).

The permanent microscope slide and others specimens are deposited in the first author's collection at the Universidad de Alcalá (Spain).

The third instar of T. alicantinus is compared with the larvae of some other species of Trechus and those of other genera/subgenera (Jeannel 1920, 1926a, Bolívar y Pieltain 1923, Coiffait 1951, Giachino 1985, 1989, Luff 1993, Makarow 1994, Grebennikov 1996, Grebennikov \& Luff 1998, Makarov \& Koval 2003, Casale \& Marcia 2007): Aepus Leach, 1819; Aepopsis Jeannel, 1922; Perileptus Schaum, 1860; Thalassophilus Wollaston, 1854; Epaphius Leach, 1819; Iberotrechus Jeannel, 1920; Duvalius Delarouzée, 1859; Geotrechus Jeannel, 1919; Speotrechus Jeannel, 1922; Neaphaenops Jeannel 1920; Typhlotrechus G. Müller, 1913; Orotrechus G. Müller, 1913; Neotrechus G. Müller, 1913; Jeannelius Kurnakov, 1959; Paraphaenops Jeannel, 1916; Sardaphaenops Cerruti \& Henrot, 1956.

\section{Description of the third instar larva of Trechus alicantinus Español, 1971}

Habitus (Fig. 1): slightly sclerotized; with notable setation; whitish with testaceous head; very slight body shape; length (from mandible to urogomphi apexes, macrosetae excluded) 8.4 $\mathrm{mm}$; legs with only one claw.

Cephalic capsule (Figs 2a,b): subsquared; longer than wide; flat; parallelized with a very slight constriction in the middle of the posterior lateral region; anophthalm. Egg-bursters and teeth-like structures absent. Long epicranial suture (epicranial suture length / head length ratio of 0.2 ). Frontal sutures clearly visible, deeply curved and sinuous. Anterior margin of epistome (nasale) (Fig. 3a) tri-lobed; slightly asymmetrical; with variable number of teeth on each site; median lobe largest and medially protruding. Isodiametric microsculpture of the integument of

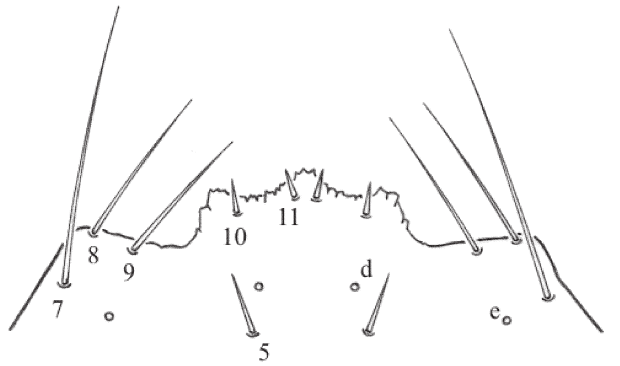

a
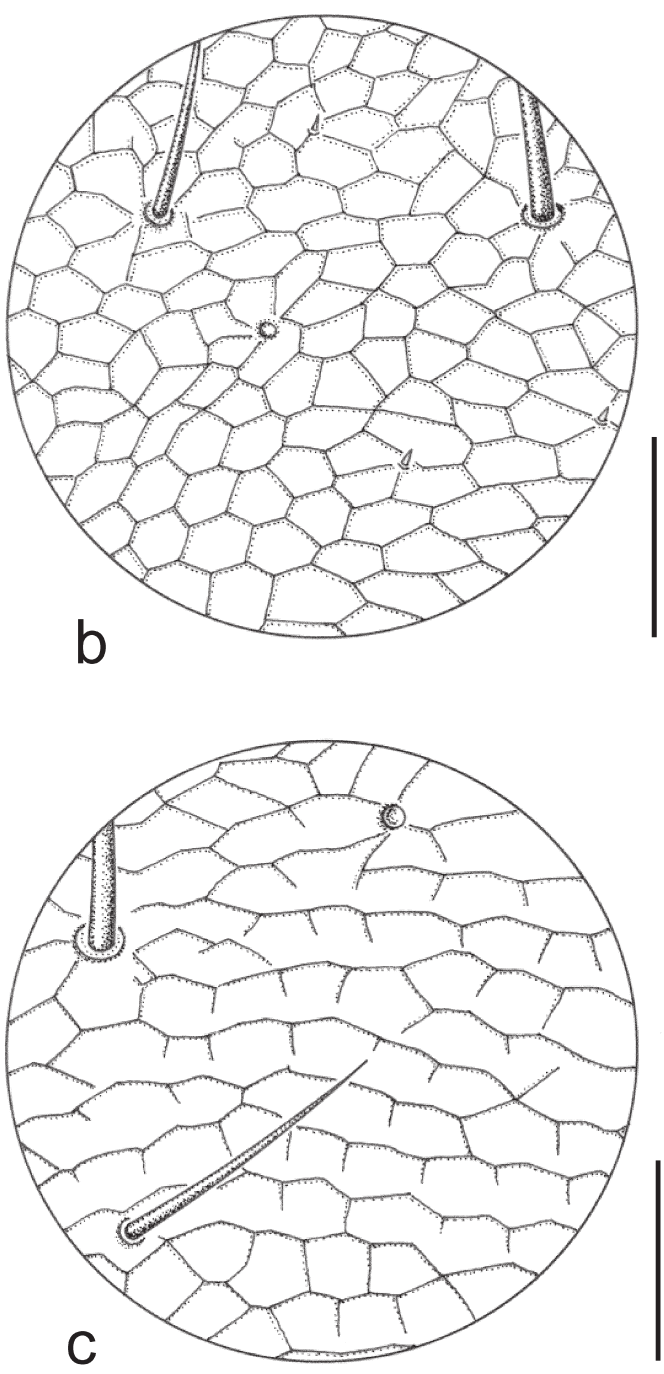

Fig. 3. Details of the cephalic capsule. - a. Nasale and anterior margin of front. $-b$. Microsculpture of the frontal sclerite in dorsal view. - c. Microsculpture of the parietal sclerite in dorsal view. Scale bar, a: 0.2 $\mathrm{mm}$; b and c: $0.05 \mathrm{~mm}$. 


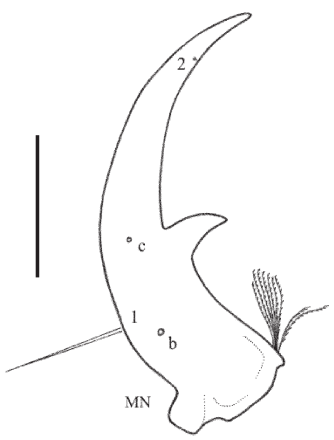

a

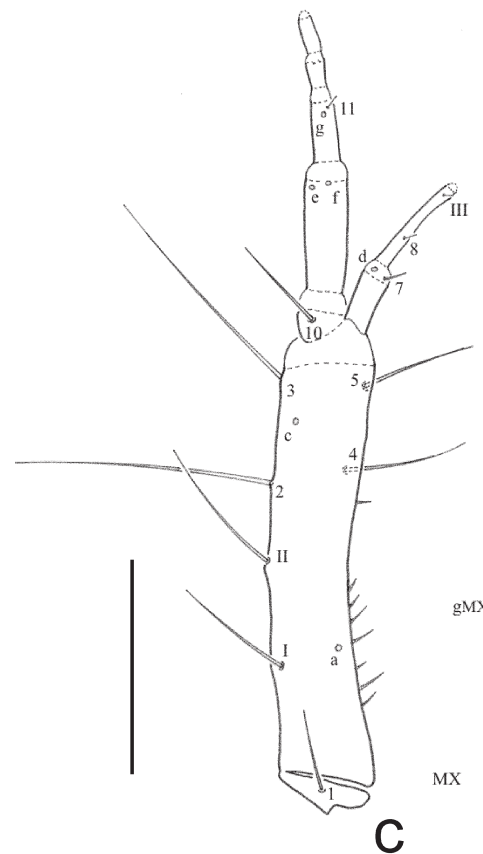

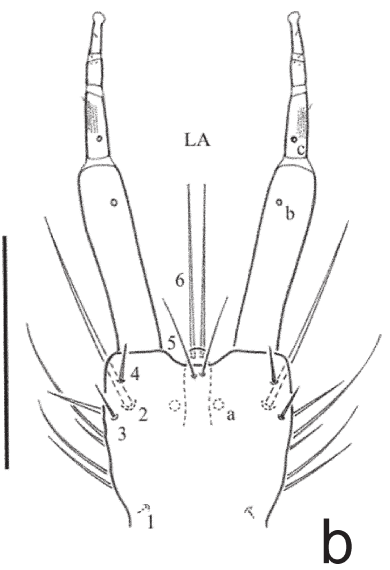

b

Fig. 4. Cephalic pieces. - a. Mandible in dorsal view. - b. Labium in dorsal view. - c. Maxilla in ventral view. - d. Cardo and stipes in dorsal view. - e. Left antenna in dorsal view. Scale bar: $0.2 \mathrm{~mm}$.

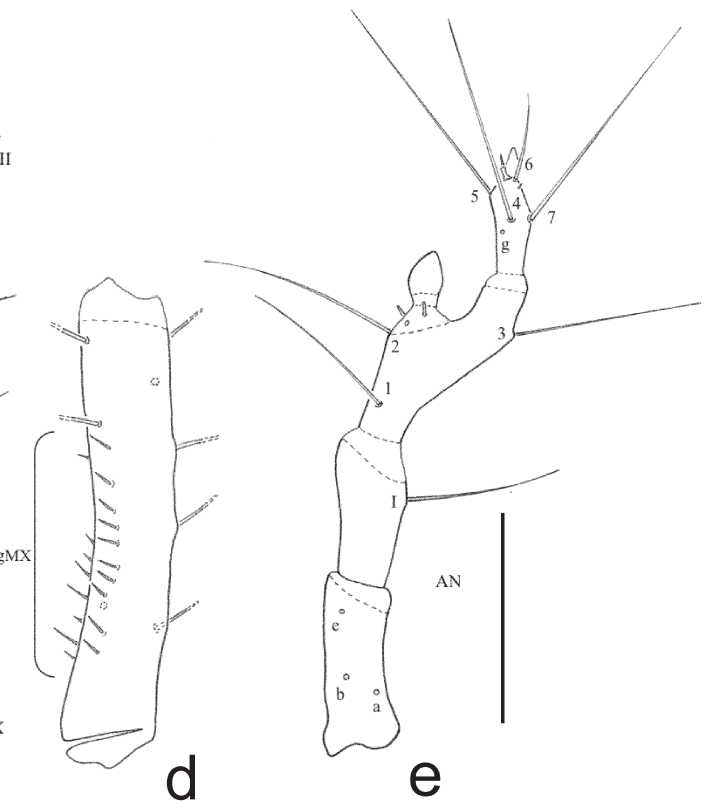

the frontal sclerite, and more or less transverse microsculpture of the parietal sclerite (Figs 3b,c).

Chaetotaxy of cephalic capsule: frontal [FR] (Fig. 2a) with 11 setae (FR1-FR11) + 1 seta (FRI) and 6 pores (FRa-FRf) in each side; FR2 and FR8 more hypertrophied. Parietal [PA] (Figs 2a,b) with 19 setae (PA1-PA19) + 22 setae (PAIPAXXII); 15 pores (PAa-PAo) and 1 additional pore (PAa) on each side; PA7, PA9, PA14 and PA14 more hypertrophied.

Mandible [MN] (Fig. 4a): falciform without addictional teeth; moderatly curved; with 2 setae (MN1-MN2) and 2 pores $(\mathrm{MNb}-\mathrm{MNc})$; penicillum moderately developed.

Labium [LA] (Fig. 4b): labial palps with 4 articles, prementum with 6 setae (LA1-LA6) and one pore (LAa) on each side; seta LA6 a little shorter than the first article of the palp, second segment with one pore (LAc) and a striated structure, probably a sensory complex according to Makarov and Koval (2003); fourth segment with sensory apex.

Maxilla [MX] (Figs 4c,d): cardo with one seta (MX1). Stipes with 4 setae $(\mathrm{MX} 2-\mathrm{MX} 5)+2$ setae (MXI-MXII) and 2 pores (MXa, MXc) and a variable number of setae (gMX); MX4 hypertrophied compared with the archetypal model (Bousquet \& Goulet 1984). Lacinia absent. Galea 

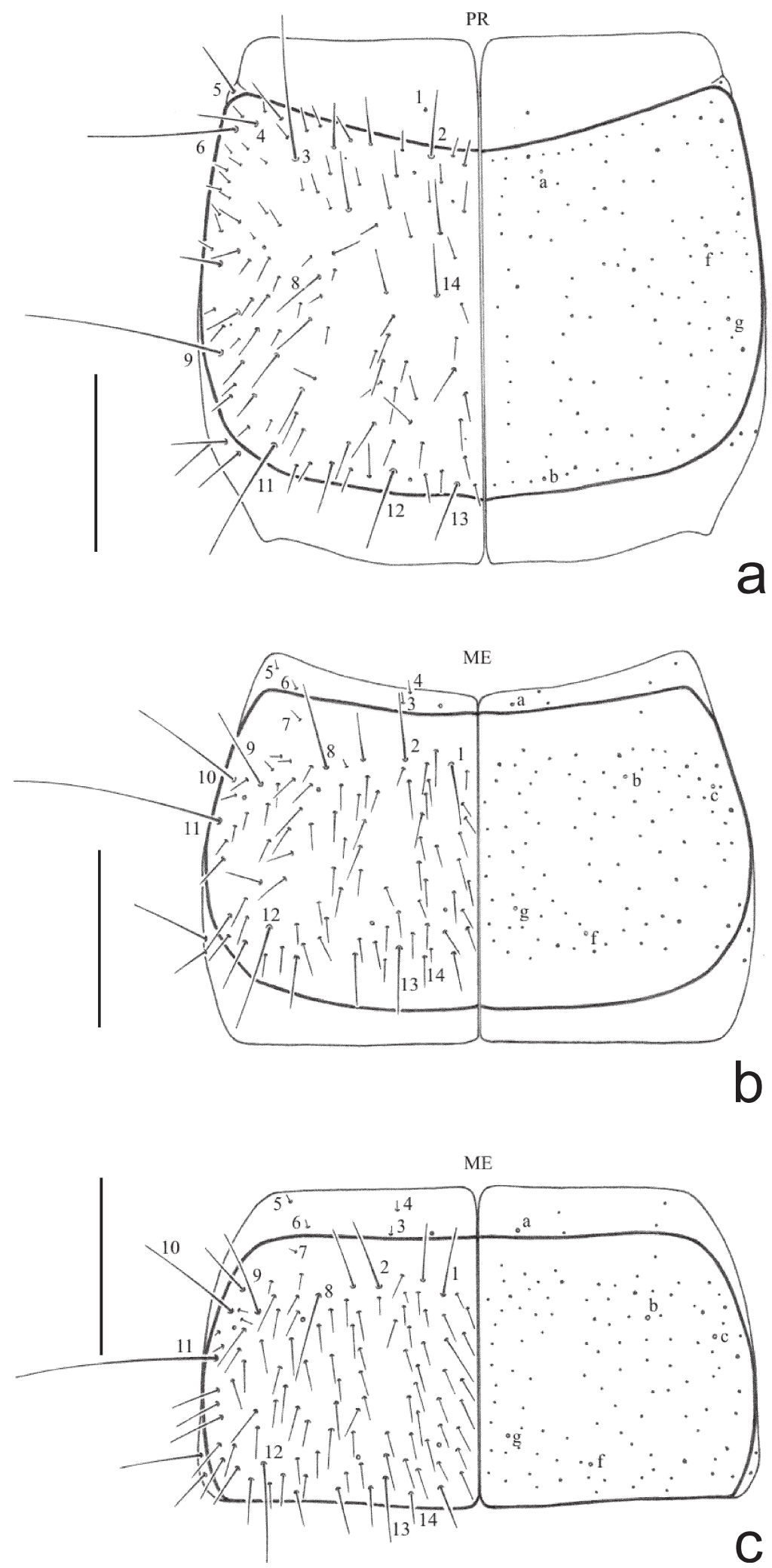

Fig. 5. Thorax in dorsal view. - a. Pronotum. 
Fig. 6. - a. Leg.

- b. Urogomphi in dorsal view. - c. Pygidium in dorsal view. - d. Pygidium in ventral view. Scale bar, a: $0.2 \mathrm{~mm}$; b-d: $0.3 \mathrm{~mm}$.

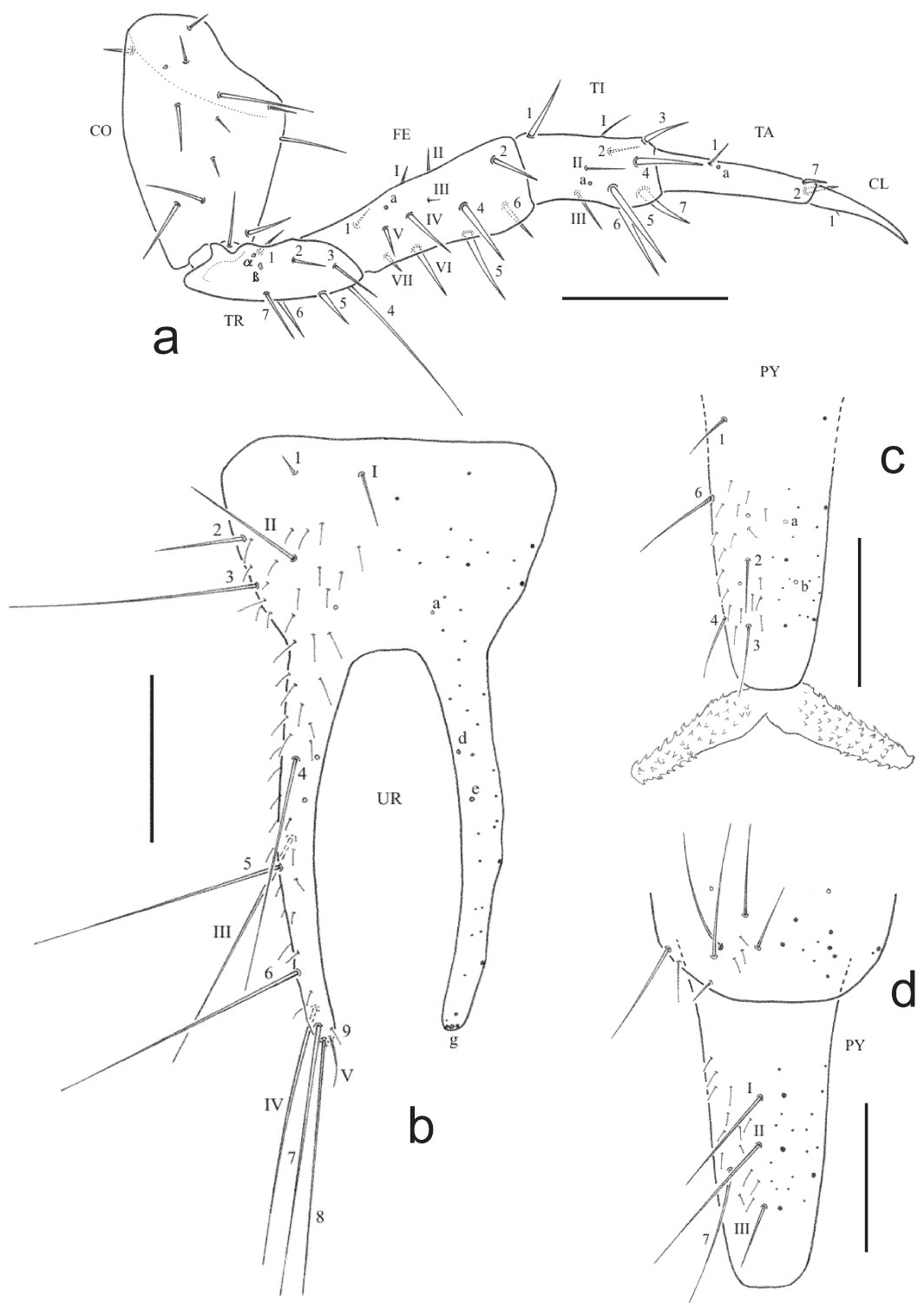

with 2 segments (appreciably half as long as maxillary palps); second larger than the first; first segment of galea with 1 setae (MX7) and one pore (MXd); second segment with 1 seta (MX8) +1 seta (MXIII) and an apical membranous sensilla. Maxillary palps with 5 segments; first segment with 1 seta (MX10); second segment with 2 pores (MXe-MXf) and larger than the others; third segment with 1 seta (MX11) and 1 pore $(\mathrm{MXg})$ and fifth segment with an apical membranous sensilla.

Antenna [AN] (Fig. 4e): with 4 articles, every one longer than wide; first segment with 3 pores (ANa-ANb and $\mathrm{ANe}$ ); second segment with 1 seta (ANI); third segment with 3 setae (AN1AN3) and a conic sensorial appendage; fourth segment with a 4 setae (AN4-AN7), one pore $(\mathrm{ANg})$ and a sensorial appendage on the apexes.

Thorax: with a heavily sclerotized area where most setae are present, with numerous additional macrosetae; prothorax biggest and subquadrate; mesothorax and metathorax transverse. Pronotum [PR] (Fig. 5a) 1.06 times longer than wide; notum with 12 setae (PR1-PR6 and PR8-PR9 
and PR11-PR14) and 4 pores (PRa, PRb, PRf, $\mathrm{PRg}$ ) on each side. Mesonotum and metanotum [ME] (Figs 5b, c) wider than long; notum with all primary setae (PR1-PR14) and all primary pores except (MEd-MEe) on each side.

Leg (Fig. 6a) with one claw: trochanter [TR] with 7 setae and 2 clearly visible pores (TR $\alpha-$ TRß); femur [FE] with 5 setae (FE1-FE2 and FE4-FE6) + 7 setae (FEI-FEVII) and 1 pore (FEa); tibia [TI] with 7 setae (TI1-TI7) + 3 setae (TII-TIIII) and 1 pore (TIa); tarsus [TA] with 3 setae (TA1-TA2 and TA7) and 1 pore (TAa); claw [CL] with one short seta (CL1).

Abdomen: urogomphi [UR] (Fig. 6b), in dorsal view, with 9 setae (UR1-UR9) + 5 setae (URI-URV) and 4 pores (URa, URd-URe, URg) on each side; UR3 very long compared with the archetipical model (Bousquet \& Goulet 1984). Pygidium [PY] (Figs 6c,d) with conical shape, 6 setae (PY1-PY4 and PY6-PY7) and the presence of two membranous structures of tubular aspect with sclerotized teeth.

\section{Discussion}

The third instar larva of T. alicantinus reveals the general characteristics of the tribe Trechini, like the absence of lacinia in the maxilla, one claw with a short seta in the leg and the presence of secondary setae (see Bousquet \& Goulet 1984, p. 577 ) on the frontal part of the cephalic capsule (Grebennikov \& Maddison 2005).

The greatest difficulty regarding the homology-based system for larvae is the confusion induced by the presence of additional setae and pores and the analysis of changes in position due to modifications of the structures when attempting to encode the ancestral setae and pores system (Bousquet \& Goulet 1984). In the present study, several microsetae were not encoded due to their very small size or because some of them do not present bilateral symmetry, which is particularly evident in the thorax and urogomphi. Dense pubescence of the body may be directly related to the life style of the larvae, as in the case of living in wet mud and sand soil (Casale \& Marcia 2007). Pubescence can retain air bubbles in immersion conditions and promote flotation in situations of sudden flooding (Carabajal et al. 1999), which would explain the amphibian life style and the capacity to inhabit subterranean (hypogean/ endogean) environments of ground beetles. This characteristic is also a common trait in several endogeous and cave-dwelling imagos of Trechini species (Laneyrie 1974), closely related with the "terrestrial-phreatic habitat" (sensu Jeannel 1926b, p. 80).

Among all the Iberian species of Trechus, those of greater size belong to the $T$. martinezilineage (Ortuño \& Arillo 2005), wich also includes T. alicantinus (length: $4.9-5.9 \mathrm{~mm}$ ).

As it would be expected, the larva of $T$. alicantinus shows subtle differences when compared with other Trechus larvae whose imagos are hypogean or epigean. These differences concern mainly the length/width of the cephalic capsule, the shape of the nasale, slight differences in the development of setae and in the presence of stemmata. As an example, compared with the chaetotaxy displayed by the larvae of other species of Trechus (see Giachino 1989), as Trechus arthuri Moravec \& Lompe, 2003 (= T. schatzmayri Focarile, 1949) the larva of $T$. alicantinus reveals the presence of additional well-developed setae ANI, MXI and MXII, URI-URIV and the absence of ANc-ANd. T. alicantinus larva differs in the nasale shape, the absence of additional pores in the frontale and the in the presence of FRV-FRVII and URIV-URV.

Regarding the development of photoreceptors, imagos of epigean (with eyes) Trechini usually exhibit larvae with stemmata, as has been found in several species of Trechus (subgenus Trechus and Epaphius). In some cases stemmata are very small and weakly pigmented (Boldori 1936), as in Perileptus, which led to some misunderstandings about the presence or absence of photoreceptors (see Luff 1993). A curious fact already observed by Jeannel (1920: 529), concerning hypogean species of Trechus, is that the larva does not express ocular structures (without stemmata), unlike adults, reinforcing the characteristics of adaptation to life in the underground environment. As a consequence, the larva expresses the absence of ocular structures, hypogean characters absent in the imago. This happens to the larva of T. breuili (see Jeannel 1920), a species also included in the "hypogean T. martinezilineage" (Ortuño 2008). However, this does not 
seem to apply to all hypogean Trechus, since according to Jeannel (1920) T. pieltaini exhibits poorly developed and pigmented stemmata. Even in lineages with a high degree of specialization in hypogean life, such as Geotrechus, Speotrechus or Neotrechus, whose imagos lack ocular structures, there are known cases of larvae which exhibit stemmata (Coiffait 1951, Makarov 1994). Otherwise, the absence of stemmata is found in other non-hypogean genera of Trechini, Aepus (see Makarow 1994) and Aepopsis (see Bolívar y Pieltain 1923, Makarow 1994, Grebennikov \& Luff 1998), or in genera that are not exclusively hypogean: Thalassophilus (see Grebennivov 1996), Iberotrechus (see Makarow 1994) and some Duvalius (see Jeannel 1920). However, many other hypogean species show larvae without stemmata, and are blind like their imagos (see Jeannel 1920, 1926a, Makarow 1994, Makarov \& Koval 2003, Casale \& Marcia 2007), e.g. Typhlotrechus, Orotrechus, Neaphaenops, Paraphaenops, Jeannelius, Sardaphaenops, among others.

Taking into account the argument presented above, we may conclude that the expression of photoreceptors in the larvae of Trechini does not seem to be directly related to the expression of photoreceptors in imagos. Similarly, it would seem that, to a great extent, the loss or conservation of stemmata in Trechini, is an event that is not fully linked to a strictly subterranean life style.

Acknowledgements. We want to express our gratitude to Juan A. Zaragoza for his collaboration in the capture of the imagos of T. alicantinus. We are also grateful to Xavier Riesco Riquelme for his revision of the English of this document.

\section{References}

Boldori, L. 1936: Larve dei Trechini VI. — Studi Trentini di Scienze Naturali 17: 65-71.

Bolívar y Pieltain, C. 1923: Descripción de la larva de un Trechini marino (Col. Carabidae). - Boletín de la Real Sociedad Española de Historia Natural 23: 5659.

Bousquet, Y. \& Goulet, H. 1984: Notation of primary setae and pores on larvae of Carabidae (Coleoptera: Adephaga). - Canadian Journal of Zoology 62: 573-588.

Carabajal, E., García, J. \& Rodríguez, F. 1999: Descripción de un nuevo género y una nueva especie de Tre- chini (Coleoptera: Caraboidea: Trechidae) de la cordillera Cantábrica. - Elytron 13: 123-131.

Casale, A. \& Marcia, P. 2007: Larval morphology of Sardaphaenops adelphus Casale, 2004, a highly specialized troglobitic beetle endemic to Sardinia (Coleoptera, Carabidae). - Subterranean Biology 5: 35-42.

Coiffait, H. 1951: Note sur les premiers états de Geotrechus orpheus ssp. consorranus et sur la biologie larvaire de ce coléoptère. - Vie et Milieu 2: 461-469.

Coquerel, C. 1850: Note pour servir à l'histoire de l'Aepus robinii et description de sa larvae. - Annales de la Société Entomologique de France 2: 529-532.

Español, F. 1971: Nuevos tréquidos cavernícolas de la fauna española (Col. Caraboidea). — Publicaciones del Instituto de Biología Aplicada de Barcelona 51: 8996.

Giachino, P. M. 1985: Morfologia larvale di alcuni Trechus alticoli delle Alpi Lepontine. — Bollettino della Societa Entomologica Italiana 117: 161-171.

Giachino, P. M. 1989: Contributo alla conoscenza della morfologia larvale del genere Trechus. La larva di Trechus schatzmayri Focarile, 1949 (Coleoptera, Carabidae). - Rivista Piemontese di Storia Naturale 10: 131-135.

Grebennikov, V. V. 1996: Description of the first instar larva of Thalassophilus longicornis (Coleoptera: Carabidae: Trechodina). - Acta Societatis Zoologicae Bohemicae 60: 373-379.

Grebennikov, V. V. \& Luff, M. L. 1998: Description of larvae of Aepopsis robini (Coleoptera: Carabidae: Trechini). — European Journal of Entomology 95: 623627.

Grebennikov, V. V. \& Maddison, D. R. 2005: Phylogenetic analysis of Trechitae (Coleoptera: Carabidae) based on larval morphology, with a description of first-instar Phrypeus and a key to genera. - Systematic Entomology 30: 38-59.

Jeannel, R. 1920: Les larves des Trechini (Coleoptera, Carabidae). - Archives de Zoologie Expérimentale et Générale 59: 509-542.

Jeannel, R. 1926a: Monographie des Trechinae. 1. — L'Abeille 32: 221-550.

Jeannel, R. 1926b: Faune Cavernicole de la France avec une étude des conditions d'existence dans le domaine souterrain. - Lechevalier, Paris. 334 pp.

Jeannel, R. 1941: Coléoptères Carabiques. Premiére partie. Faune de France, 40 - Lechevalier, Paris. 571 pp.

Laneyrie, R. 1974: Sur la systematique des Trechinae (Coleoptera: Trechidae). - Nouvelle Revue Française d'Entomologie 4: 3-21.

Luff, M. L. 1993: The Carabidae (Coleoptera) larvae of Fennoscandia and Denmark. - Fauna Entomologica Scandinavica 27: 1-187.

Makarow, K. V. 1994: A key to the genera of the Groundbeetle larvae (Coleoptera, Carabidae) of the Palearctic region. - Bollettino del Museo Regionale di Scienze Naturali, Torino 12: 221-254.

Makarov, K. V. \& Koval, A. G. 2003: A Contribution to the Knowledge of the Biology of a Troglobiont Carabid Species, Jeannelius birsteini Ljovuschkin, 1963 (Co- 
leoptera, Carabidae, Trechini). — Entomological Review 83: 819-826.

Ortuño, V. M. 2006: Coleoptera: Cicindelidae y Carabidae. — In: Domingo, J., Montagud, S. \& Sendra, A. (eds.), Invertebrados endémicos de la Comunitat Valenciana. Valencia: 137-156. Conselleria de Territori i Habitatge. Generalitat Valenciana, Valencia. 254 pp.

Ortuño, V. M. 2008: Taxonomy and Systematics of a Hypogean Trechine from Southern Spain: Trechus breuili Jeannel (Coleoptera: Carabidae). - The Coleopterists Bulletin 62: 501-507.

Ortuño, V. M. \& Arillo, A. 2005: Description of a new hy- pogean species of the genus Trechus Clairville, 1806 from eastern Spain and comments on the Trechus martinezi-lineage (Coleoptera: Adephaga: Carabidae). Journal of Natural History 39: 3483-3500.

Rapoport, E. H. 1975: Aerografía. Estrategias geográficas de las especies. - Fondo de Cultura Económica, México. 214 pp.

Serrano, J. 2003: Catálogo de los Carabidae (Coleoptera) de la Península Ibérica. (Monografías S.E.A.-9). Sociedad Entomológica Aragonesa, Zaragoza. 130 pp. 